\title{
Perbandingan Penerapan Metode Brainstorming dan Buzz Group Terhadap Peningkatan Pengetahuan Suami Ibu Hamil Tentang Tanda Bahaya Kehamilan, Persalinan, Dan Nifas (Studi Kasus Di Bogor)
}

\author{
Winancy $^{1^{*}}$, Ardini S. Raksanagara ${ }^{2}$,Yoni Fuadah ${ }^{3}$. \\ ${ }^{1}$ Jurusan Kebidanan Poltekkes Kemenkes Jakarta III, Indonesia \\ ${ }^{2}$ Departemen Ilmu Kesehatan Masyarakat Fakultas Kedokteran Universitas Padjadjaran, Indonesia \\ ${ }^{3}$ Departemen Forensik Rumah Sakit Hasan Sadikin Bandung, Indonesia
}

Informasi Artikel:

Diterima: Mei, 2015

Disetujui: Oktober, 2015

${ }^{*}$ Korespondensi penulis. winancygunawan@gmail.com

\begin{abstract}
ABSTRAK
Suami ibu hamil sebagai pengambil keputusan dalam keluarga penting diberi Pendidikan Kesehatan tentang tanda bahaya kehamilan, persalinan, dan nifas untuk meningkatkan perannya dalam mencegah situasi 3 terlambat yang menjadi penyebab tidak langsung kematian ibu di Indonesia. Metode brainstorming dan buzz group dalam Pendidikan Kesehatan dapat menstimulasi peran aktif peserta diskusi sehingga informasi yang diberi lebih mudah diterima.

Penelitian ini adalah penelitian Quasi Experiment dengan rancangan Non Randomized PretestPosttest Design. Populasi penelitian adalah suami yang istrinya sedang hamil di wilayah kerja Puskesmas Sukamakmur Kabupaten Bogor di Desa Sirnajaya dan Desa Cibadak. Metode pengambilan sampel adalah secara accidental sampling yang terdiri dari dua kelompok, yaitu kelompok brainstorming sebanyak 63 responden dan kelompok buzz group sebanyak 61 responden. Analisis uji statistik menggunakan uji Wilcoxon dan Mann-Whitney.
\end{abstract}

Hasil penelitian menunjukkan bahwa pengetahuan responden sebelum dan segera setelah proses Pendidikan Kesehatan mengalami peningkatan $(\mathrm{p}<0,001)$. Hasil uji Mann-Whitney menunjukkan bahwa peningkatan nilai median pengetahuan responden pada kelompok buzz group adalah lebih baik dibandingkan brainstorming. Metode Pendidikan Kesehatan brainstorming dan buzz group mempunyai pengaruh terhadap pengetahuan responden tentang tanda bahaya kehamilan, persalinan, dan nifas.

Kata kunci: Brainstorming; Buzz Group; Pengetahuan; Tanda bahaya kehamilan.

\begin{abstract}
It is important to give the husbands of pregnant women, as decision makers in the family, health education about the danger signs in pregnancy, childbirth, and postpartum. Methods of brainstorming and buzz group on health education are able to stimulate the active role of participants of a discussion, so they accept the information given to them more easily.

This was a Quasi Experimental Study with Non Randomized Pretest-Posttest design. Population in this study consisted of the husbands whose wife was pregnant and lived in the work area of Sukamakmur Puskesmas (Community Health Center) in Bogor District. Accidental sampling method was used and it involved two groups, namely brainstorming group consisting of 63 respondents and buzz group consisting of 61 respondents. Statistical analysis used Wilcoxon and Mann-Whitney tests.
\end{abstract}

The results showed that the respondents knowledge was improved immediately after the health education had been given $(p<0.001)$. The results of Mann-Whitney test described that the increased median value of knowledge of the respondents in buzz group was better than that in brainstorming group. The conclusion shows that Buzz group has better impacts on the increased median value of the respondents' knowledge.

Key Words: Brainstroming, Buzz Group; Knowledge; Danger sign of pregnancy. 


\section{PENDAHULUAN}

Angka kematian ibu merupakan indikator yang menunjukkan status kesehatan perempuan di suatu negara. Angka kematian ibu di Indonesia masih cukup tinggi jika dibandingkan dengan negara Association South East Asian Nation (ASEAN) lainnya seperti Malaysia. Kematian ibu di Indonesia diperkirakan terjadi pada 20 ribu dari lima juta kelahiran setiap tahun, risiko kematian ibu melahirkan di Indonesia adalah 1 dari 65 dibandingkan dengan 1 dari 1.100 ibu melahirkan di Thailand (Kemenkes, UNFPA, 2012).

Studi tindak lanjut Sensus Penduduk (SP) 2010 yang dilakukan oleh Badan Litbangkes Kementerian Kesehatan Republik Indonesia menunjukkan bahwa AKI meningkat jika dibandingkan tahun 2007 (Kemenkes, 2012), yaitu dari 228 per 100.000 kelahiran hidup $(\mathrm{KH})$ menjadi 278 per $100.000 \mathrm{KH}$ pada tahun 2010 . Data Survei Demografi Kesehatan Indonesia (SDKI) tahun 2012 menunjukkan bahwa AKI di Indonesia meningkat menjadi 359 per 100.000 kelahiran hidup (KH) (Kemenkes BKKBN, BPS 2012).

Salah satu penyebab tidak langsung kematian ibu di Indonesia adalah kondisi situasi "3 terlambat", yaitu terlambat mengambil keputusan, terlambat merujuk, dan terlambat mendapat pertolongan. Terlambat mengambil keputusan disebabkan karena ibu dan keluarga tidak mengenali tanda bahaya pada kehamilan, persalinan, dan nifas (BPS, BKKBN, 2008). Kegiatan dalam upaya penurunan AKI sebagai akibat situasi "3 terlambat" dilakukan dengan pemberdayaan masyarakat, sasaran, dan keluarga dalam mengenal serta merujuk kasus risiko tinggi tepat waktu melalui Pendidikan Kesehatan dan Konseling (Wijono, 2008). Suami memiliki peran yang sangat penting dalam upaya perlindungan kesehatan istri dan anak. Suami sebagai kepala rumah tangga harus mampu mengambil keputusan yang baik bagi kesehatan ibu dan anak, yaitu keputusan yang baik didukung oleh pengetahuan yang cukup terhadap masalah tersebut. Pengetahuan yang penting harus dimiliki suami adalah pengetahuan tentang tanda bahaya kehamilan, persalinan, dan nifas sehingga dapat mencegah terlambat mengenali tanda bahaya dan mengambil keputusan untuk merujuk jika diperlukan (Harymawan, 2007).

Profil Dinas Kesehatan Kabupaten Bogor menunjukkan cakupan komplikasi kebidanan yang ditangani oleh tenaga kesehatan di fasilitas lebih lengkap seperti Puskesmas dan RS hanya mencapai 53,91\% (target Kabupaten 70\%). Hal ini dapat terjadi karena adanya keterlambatan merujuk kasus komplikasi. Puskesmas Sukamakmur memiliki $424 \mathrm{ibu}$ hamil yang mengalami komplikasi kebidanan, namun hanya 86 kasus atau $20,3 \%$ yang dapat ditangani oleh tenaga kesehatan. Terlambat mengenal tanda bahaya oleh ibu hamil dan keluarga menyebabkan terlambat mengambil keputusan untuk merujuk dan mendapat pertolongan (Profil Kesehatan Kabupaten Bogor, 2010). Berdasarkan survei sederhana yang dilakukan oleh Poltekkes Kemenkes Jakarta III Jurusan Kebidanan pada awal tahun 2012 di Desa Sukasirna Kabupaten Bogor, dari 133 Ibu hamil, 50 orang merencanakan bersalin di paraji karena alasan diminta suami, dan $81,20 \%$ Ibu hamil tersebut menyatakan tidak mengetahui tentang tanda bahaya pada kehamilan, persalinan dan nifas meskipun telah memiliki buku KIA (Laporan Praktik Kebidanan Komunitas Poltekkes JKT III, 2012).

Penelitian yang menunjukkan peran suami dan keluarga dalam pengambilan keputusan tentang kesehatan ibu dan anak sudah banyak dilakukan, salah satunya adalah penelitian tentang evaluasi implementasi program Jampersal yang dilakukan Badan Litbangkes Kemenkes RI pada tahun 2012. Jampersal adalah salah satu program Pemerintah dalam usaha menurunkan AKI, namun dalam pelaksanaannya masih banyak ibu hamil dan bersalin yang tidak memanfaatkan program tersebut karena alasan dilarang oleh suami sebesar 29\%(Rachmawati,2013). 
Penelitian Risbinakes Badan Litbangkes oleh Aimanah Ira Ummu dkk menunjukkan hasil bahwa pengetahuan suami dan keluarga tentang Program Perencanaan Persalinan dan Pencegahan Komplikasi (P4K) adalah masih rendah. Penelitian ini juga menyebutkan bahwa pengambil keputusan dalam memilih tempat persalinan dan transportasi yang digunakan adalah suami, sebagai pemegang keputusan ketika kondisi istri dalam gawat darurat (Aimanah, 2011). Pengetahuan suami tentang tanda bahaya kehamilan, persalinan, nifas dan neonatal di Kabupaten Garut tahun 2007 hanya mencapai skor 28 dari total skor pengetahuan 104. Pengetahuan yang rendah ini menjadi salah satu indikator rendahnya derajat kesehatan ibu di wilayah tersebut (Sholilah, 2009).

Kemampuan wanita untuk mencari pelayanan kesehatan atau menerapkan pengetahuan dari sebuah intervensi pendidikan kesehatan sering ditentukan oleh kepala rumah tangga, yaitu suami. Dukungan dan peran suami dalam masa kehamilan terbukti meningkatkan kesiapan Ibu hamil dalam menghadapi proses persalinan. Budaya beberapa kelompok masyarakat di Indonesia menunjukkan peran suami atau keluarga dalam mengambil keputusan di keluarga adalah sangat dominan (budaya Paternalistik) (Balitbangkes, 2007). Kurangnya pengetahuan suami dan keluarga tentang tanda bahaya kehamilan, persalinan dan nifas menjadi faktor yang berkontribusi terhadap tingginya AKI (Norhajati, Dewi VK, Inayah HK, 2010) sehingga pengetahuan suami dan keluarga menjadi penting dalam mengenali tanda bahaya kehamilan, persalinan, dan nifas.

Pendidikan Kesehatan untuk mencapai tujuan yang ditetapkan dipengaruhi oleh beberapa faktor, diantaranya petugas yang memberikan pendidikan, media yang digunakan, materi pendidikan, dan metode yang digunakan. Suami ibu hamil perlu diberikan Pendidikan Kesehatan untuk meningkatkan pengetahuan dan sikapnya tentang tanda bahaya kehamilan, persalinan, dan nifas dengan metode partisipatif. Keluarga merupakan sasaran yang bermakna dalam memperhatikan tanda bahaya kehamilan, persalinan, dan nifas terutama suami yang memiliki peran sebagai pengambil keputusan dan bertanggung jawab terhadap status kesehatan anggota keluarga (Sholihah, 2009). Pendidikan Kesehatan pada suami ibu hamil dapat dilakukan pada waktu senggang, yaitu setelah jam kerja dalam situasi nonformal sehingga mudah diterima.

Pendidikan Kesehatan merupakan kegiatan yang diharapkan dapat meningkatkan pengetahuan suami dan berpengaruh pada perilaku. Penelitian tentang pendidikan kesehatan yang dilakukan di Nepal pada tahun 2006 menunjukkan bahwa wanita hamil yang menerima pendidikan kesehatan dengan suaminya lebih cenderung melakukan kunjungan pasca persalinan dibandingkan hanya wanita hamil saja yang menerima pendidikan kesehatan (Mullany BC, Becker S, Hindin MJ, 2007).

Metode yang mampu menstimulasi peran aktif peserta adalah, antara lain, diskusi kelompok brainstorming dan buzz group. Metode brainstorming merupakan diskusi kelompok dengan jumlah peserta diskusi tidak lebih dari 15 orang yang dilakukan dengan memberikan suatu topik atau masalah. Kemudian, setiap peserta akan memberikan pendapat yang akan ditulis dalam sebuah flipchart atau papan tulis tanpa sanggahan. Setelah semua peserta mengeluarkan pendapat, peserta lain dapat memberikan tanggapan atau saran pada pendapat yang telah ada.

Metode brainstorming merupakan cara untuk mendapatkan banyak ide dalam waktu singkat Roetiyah, 2001). Metode buzz group digunakan dalam kegiatan pembelajaran untuk memecahkan suatu masalah. Peserta dibagi dalam kelompokkelompok kecil dengan jumlah 2-5 peserta yang akan melakukan diskusi dalam waktu singkat tentang masalah/materi yang sama ataupun tidak sama. Hasil diskusi kelompok-kelompok kecil ini akan dilanjutkan dengan diskusi dalam kelompok besar untuk mendapatkan kesimpulan (Tourney, R, 2012; Scout, 2013; Russel, 2013) 
Rumusan masalah dalam penelitian ini adalah apakah metode buzz group dalam Pendidikan Kesehatan dapat meningkatkan pengetahuan dan sikap suami ibu hamil tentang tanda bahaya kehamilan, persalinan, dan nifas lebih baik dibandingkan dengan metode brainstorming. Tujuan penelitian ini adalah untuk mengetahui pengaruh metode brainstorming dan buzz group dalam Pendidikan Kesehatan terhadap peningkatan pengetahuan dan sikap suami ibu hamil tentang tanda bahaya kehamilan, persalinan, dan nifas.

\section{BAHAN DAN METODE}

Metode Pendidikan Kesehatan brainstorming dan buzz group merupakan metode diskusi kelompok kecil yang diikuti oleh peserta kurang dari 15 orang. Penerapan metode ini memungkinkan peserta diskusi dapat berperan serta dalam diskusi dengan bebas dan dalam suasana santai. Lokasi penelitian ditetapkan 2 (dua) desa, yaitu 1 desa (Desa Cibadak) untuk kelompok yang akan diberikan Pendidikan Kesehatan dengan metode brainstorming dan 1 desa (desa Sirnajaya) dengan metode buzz group.

Penelitian ini menggunakan metode eksperimen semu (quasi experiment) dengan rancangan pretest-posttest design. Jenis eksperimen ini membandingkan pengetahuan responden pada dua kelompok perlakuan yang diberikan Pendidikan Kesehatan dengan metode brainstorming dan buzz group (Satari, MH, Wirakusumah FF, 2011; Notoatmodjo, S. 2012).

Populasi target dalam penelitian ini adalah seluruh suami yang istrinya sedang hamil saat penelitian berlangsung. Populasi terjangkau penelitian ini adalah suami ibu hamil yang tinggal menetap di lokasi penelitian selama periode pengumpulan data. Pengambilan sampel dilakukan secara non random sampling dan bersifat accidental sampling. Responden yang hadir dan bersedia berperan serta dalam penelitian akan diikutsertakan dengan kriteria mampu baca tulis serta tidak berprofesi sebagai tenaga kesehatan. Tingkat pengetahuan responden akan dinilai sebelum dan setelah proses Pendidikan Kesehatan. Posttest akan dilakukan 2 kali, yaitu segera setelah proses Pendidikan Kesehatan dan satu minggu setelah proses Pendidikan Kesehatan.

Pendidikan Kesehatan di Desa "S" menggunakan metode buzz group dengan jumlah responden yang hadir 61 orang dan dilaksanakan pada bulan Januari sampai Februari 2014. Pendidikan Kesehatan di Desa "C" menggunakan metode brainstorming dengan jumlah responden 63 dilaksanakan pada bulan Februari 2014. Total responden adalah 124 dari dua kelompok. Uji statistik yang digunakan adalah uji Wilcoxon karena data tidak berdistribusi normal. Analisis untuk mengetahui perbandingan pengaruh metode brainstorming dan buzz group dalam Pendidikan Kesehatan menggunakan uji Mann-Whitney. Alat ukur yang digunakan adalah kuesioner yang telah diuji validitas dengan menggunakan uji Product Moment Pearson dan uji reliabilitas dengan menggunakan rumus Cronbach Alpha (Satari, MH, Wirakusumah, FF, 2011).

Hasil uji statistik pada penelitian ini menggunakan nilai median dan bukan mean karena data yang didapatkan tidak berdistribusi normal.

\section{HASIL DAN PEMBAHASAN}

Tabel 1.

Perbedaan pengetahuan suami ibu hamil sebelum dan sesudah Pendidikan Kesehatan pada kelompok brainstorming dan buzz group

\begin{tabular}{|c|c|c|c|}
\hline \multirow[t]{2}{*}{ Variabel } & \multirow[t]{2}{*}{ Perbedaan } & $\begin{array}{l}\text { Brainstorming } \\
(\mathrm{n}=63)\end{array}$ & $\begin{array}{c}\text { Buzz, Group } \\
(\mathrm{n}=61)\end{array}$ \\
\hline & & Nilai p* & Nilai $p^{*}$ \\
\hline \multirow[t]{3}{*}{ Pengetahua } & $\begin{array}{l}\text { Pretest } \\
\text { dan } \\
\text { Posttest } 1\end{array}$ & $<0,001$ & $<0,001$ \\
\hline & $\begin{array}{l}\text { Pretest } \\
\text { dan } \\
\text { Posttest } 2\end{array}$ & $<0,001$ & $<0,001$ \\
\hline & $\begin{array}{l}\text { Posttest } 1 \\
\text { dan } \\
\text { Posttest }\end{array}$ & $<0,001$ & 0,126 \\
\hline
\end{tabular}

Hasil uji Wilcoxon yang menunjukkan bahwa perubahan pengetahuan responden pada kelompok. 
brainstorming pada pretest dan posttest 1 , pretest dan posttest 2, serta posttest 1 dan posttest 2 memiliki nilai $\mathrm{p}<0,001$, yang berarti bahwa perubahan atau peningkatan pengetahuan adalah sangat bermakna. Kelompok buzz group menunjukkan perubahan pengetahuan yang bermakna pada pretest dan posttest 1 , serta pretest dan posttest 2 dengan nilai $\mathrm{p}<0,001$ tetapi posttest 1 menunjukkan nilai $\mathrm{p}>0,05$ pada dan posttest 2 menunjukkan $\mathrm{p}=0,126$. Hal ini berarti bahwa pengetahuan responden pada posttest 1 dibandingkan posttes 2 di kelompok buzz group tidak mengalami peningkatan yang bermakna.

\section{Tabel 2.}

Peningkatan pengetahuan suami ibu hamil sebelum dan sesudah Pendidikan Kesehatan pada kelompok brainstorming dan buzz group

\begin{tabular}{|c|c|c|c|}
\hline \multirow{2}{*}{$\begin{array}{l}\text { Variabel } \\
\text { Pengetahuan } \\
\text { (Skala 100) }\end{array}$} & \multicolumn{2}{|l|}{ Kelompok } & \multirow{2}{*}{$\begin{array}{l}\text { Nilai } \\
\text { p* }\end{array}$} \\
\hline & $\begin{array}{l}\text { Brainstorming } \\
(\mathrm{n}=63)\end{array}$ & $\begin{array}{l}\text { Buzz, Group } \\
(\mathrm{n}=61)\end{array}$ & \\
\hline Pretest & $52,9(16,9)$ & $52,1(17,3)$ & 0,529 \\
\hline Rerata (SD) & 53,3 & 46,6 & \\
\hline Median & $13,3-93,3$ & $26,7-93,3$ & \\
\hline \multicolumn{4}{|l|}{ Rentang } \\
\hline \multicolumn{4}{|l|}{ Posttest 1} \\
\hline Rerata (SD) & $84,3(8,3)$ & $78,3(11,1)$ & 0,001 \\
\hline Median & 86,6 & 80,0 & \\
\hline Rentang & $66,7-100$ & $53,3-100$ & \\
\hline Posttest 2 & $68,9(17,5)$ & $74,8(16,6)$ & 0,044 \\
\hline Rerata (SD) & 73,3 & 80,0 & \\
\hline Median & $13,3-93,3$ & $33,3-100$ & \\
\hline Rentang & & & \\
\hline
\end{tabular}

Berdasarkan hasil uji Mann-Whitney, skor pengetahuan responden pada kelompok brainstorming dan buzz group sebelum diberi Pendidikan Kesehatan dapat disimpulkan menunjukkan nilai median yang tidak jauh berbeda, yaitu 53,3 dan 46,6 dengan nilai $\mathrm{p}>0,05$ $(p=0,529)$. Hal ini berarti bahwa tingkat pengetahuan responden pada kedua kelompok adalah tidak berbeda. Nilai median pengetahuan responden pada posttest 1 yang dinilai segera setelah proses Pendidikan Kesehatan adalah 86,6 pada kelompok brainstorming dan 80,0 pada kelompok buzz group. Hal ini berarti bahwa terdapat peningkatan nilai pengetahuan responden pada kedua kelompok dan peningkatan ini adalah sangat bermakna dengan nilai $p=0,001$. Nilai median pengetahuan responden pada posttest 2 yang dinilai 1 minggu setelah proses Pendidikan Kesehatan mengalami peningkatan dibandingkan sebelum Pendidikan Kesehatan tetapi menurun jika dibandingkan nilai median posttest 1 . Namun demikian, peningkatan yang ada tetap bermakna dengan nilai $\mathrm{p}=0,044$.

Metode brainstorming dan buzz group merupakan metode Pendidikan Kesehatan yang membantu peserta memadukan pengetahuan yang telah lama dimiliki dengan pengetahuan baru karena peserta diberi kesempatan untuk mengajukan pertanyaan atau pernyataan untuk menghubungkan informasi baru dengan informasi yang dimiliki sebelumnya. Metode ini dapat membantu peserta diskusi dalam mengembangkan pemahaman yang lebih baik. Terjadi peningkatan pengetahuan merupakan indikator keberhasilan Pendidikan Kesehatan dengan metode yang digunakan (Notoatmodjo, 2012).

Metode pendidikan brainstorming dan buzz group merupakan modifikasi dari metode diskusi kelompok kecil. Antar peserta diskusi dapat saling bertukar informasi dan pengalaman tentang tanda bahaya kehamilan, persalinan, dan nifas sehingga tidak menimbulkan kebosanan, dapat menarik perhatian, dan menimbulkan rangsangan untuk diikuti dengan tujuan bahwa pengetahuan peserta dapat lebih menyeluruh (Notoatmodjo, 2012).

Metode Pendidikan Kesehatan dengan diskusi kelompok adalah sangat tepat diberikan pada responden yang berprofesi sebagai petani. Hal ini didukung oleh penelitian yang dilakukan oleh Arshed dkk (Arshed, AW, Ch KM, Iqbal, Husain A, 2012) di Punjab Pakistan tentang efektivitas metode pendidikan dan penyebaran informasi di kalangan petani jagung. Penelitian ini menunjukkan hasil bahwa 43,3\% petani jagung lebih memilih pendidikan atau penyebaran informasi melalui diskusi kelompok dibandingkan dengan metode lain. 
Metode belajar yang digunakan mengacu pada prinsip bahwa pengetahuan yang dimiliki oleh banyak panca indera yang digunakan untuk menerima pengetahuan, maka akan semakin jelas pengertian yang didapat (Notoatmodjo, 2012). Diskusi kelompok adalah metode pendidikan yang melibatkan lebih dari satu panca indera peserta. Hasil penelitian Norhajati, dkk 2010 menunjukkan bahwa terdapat perbedaan pengetahuan responden yang diberikan Pendidikan Kesehatan dengan metode ceramah dan metode partisipatif dengan nilai $\mathrm{p}=0,046$, yang berarti bahwa metode partisipatif adalah lebih baik dibandingkan dengan ceramah (Norhajati, Dewi VK, Inayah HK, 2010).

Tanda bahaya kehamilan, persalinan, dan nifas merupakan tanda dan gejala yang dialami ibu hamil, bersalin, dan nifas dan dapat membahayakan jiwa ibu dan janin yang dikandungnya. Keluarga menjadi orang terdekat dan bertanggung jawab dalam mengetahui, memahami, dan memperhatikan tanda bahaya kehamilan, persalinan, dan nifas, terutama suami yang memiliki peran besar dalam menentukan status kesehatan keluarganya dan mengambil keputusan saat istri mengalami tanda bahaya dalam kehamilan, persalinan, dan nifas (Nurlianawati, 2012).

Suami berperan sebagai fasilitator bagi keluarganya, yaitu memfasilitasi, memenuhi kebutuhan, dan menemani istri saat akan memeriksakan kesehatan reproduksi. Berbagai penelitian tentang pengaruh suami dalam perawatan kesehatan reproduksi istri memberi dampak positif dalam perawatan dan pencegahan komplikasi kehamilan (Kakaire O, Kaye DK, Osinde MO, 2011; Mullany BC, Becker S, Hindin MJ, 2007). Pengetahuan suami yang rendah tentang perawatan kehamilan yang sehat dan pencegahan komplikasi akibat kehamilan, persalinan, dan nifas pada istri akan berkontribusi pada angka kematian ibu.

Suami juga berperan sebagai edukator, yaitu memberikan informasi yang tepat pada istri tentang kesehatan reproduksi. Pengaruh suami sebagai kepala rumah tangga dan pengambil setiap orang diterima oleh panca indera. Semakin

keputusan menjadikan suami sebagai pihak yang lebih didengar dan diikuti sarannya oleh istri, terutama tentang perawatan kehamilan dan pencegahan komplikasi. Pengetahuan suami yang cukup tentang kehamilan, persalinan, dan nifas akan meningkatkan kesadaran suami bahwa keselamatan ibu dan bayi menjadi tanggung jawab bersama. Pendidikan Kesehatan tentang tanda bahaya kehamilan, persalinan, dan nifas merupakan suatu informasi yang penting untuk diberikan pada suami ibu hamil. Agar informasi ini dapat diterima dengan mudah, informasi ini diberikan dengan tehnik dan metode yang bersifat santai, yaitu brainstorming dan buzz group.

Pengetahuan suami tentang tanda bahaya kehamilan, persalinan, dan nifas merupakan stimulasi penting terhadap tindakan positif dalam mengambil keputusan yang tepat di saat istri mengalami tanda bahaya. Perilaku yang didasari oleh pengetahuan akan lebih langgeng dibandingkan perilaku yang tanpa didasari oleh pengetahuan. Pengetahuan merupakan domain yang sangat penting dalam membentuk tindakan seseorang (Notoatmodjo, 2012).

Hasil penelitian Norhajati dkk menyatakan bahwa metode Pendidikan Kesehatan yang partisipatif adalah lebih baik dalam meningkatkan pengetahuan dibandingkan dengan metode ceramah (Norhajati, Dewi VK, Inayah HK, 2010). Hasil penelitian oleh Hapsari yang melakukan penelitian tentang efektivitas metode brainstorming dalam meningkatkan pengetahuan dan sikap mengenai ASI eksklusif pada ibu hamil di Semarang menunjukkan bahwa metode brainstorming adalah sama efektifnya dengan metode ceramah dalam meningkatkan pengetahuan ibu $(\mathrm{p}<0,05)$, tetapi penggunaan metode brainstorming adalah lebih efektif untuk meningkatkan sikap dibandingkan dengan metode ceramah (Hapsari, 2007).

Hasil penelitian Lia Nurlianawati tentang pengaruh diskusi kelompok tentang perawatan kehamilan terhadap pengetahuan dan sikap 
keluarga di wilayah Puskesmas Cihampelas Kabupaten Bandung Barat menunjukkan hasil bahwa metode diskusi kelompok berpengaruh terhadap peningkatan sikap keluarga dalam

perawatan kehamilan dengan nilai $\mathrm{p}<0,001$ $(\mathrm{p}=0,000)$, dan metode partisipatif adalah lebih baik untuk meningkatkan sikap keluarga dibandingkan dengan metode ceramah dengan nilai $\mathrm{p}=0,002$ (Nurlianawati, L, 2012).

Penelitian Winarsi tentang pengaruh Pendidikan Kesehatan dengan metode diskusi kelompok terhadap keluhan dalam kehamilan ibu hamil di asrama group II Kopassus menunjukkan hasil bahwa pendidikan kesehatan dengan metode diskusi kelompok mampu meningkatkan pengetahuan dengan nilai pretest rata-rata 11,16 dan nilai posttest rata-rata 12,80 dan terjadi peningkatan pengetahuan 1,64. Penilaian sikap menunjukkan nilai pretest 13,56 dan posttest 14,32 dan terjadi peningkatan 0,76 (Winarsi, 2006).

Hasil penelitian ini menunjukkan bahwa pengaruh Pendidikan Kesehatan dengan metode brainstorming dan buzz group dapat meningkatkan pengetahuan responden secara signifikan dengan nilai $\mathrm{p}<0,05 \quad(\mathrm{p}=0,001)$ pada posttest 1 dan $\mathrm{p}=0,044$ pada posttest 2 . Pengetahuan responden mengalami penurunan kemaknaan hasil uji statistik pada posttest 2. Berdasarkan hasil evaluasi kegiatan yang dilakukan oleh tim peneliti, hal ini dapat dikarenakan materi pendidikan kesehatan yang diberikan merupakan materi baru bagi responden, proses pendidikan yang hanya 1 kali pertemuan sedangkan pengaruh metode pendidikan lebih baik jika diterapkan dalam 3-4 kali pertemuan (Sucipto B, 2006), dan rentang waktu penilaian posttest 2 yang hanya 1 minggu pasca Pendidikan Kesehatan sehingga dimungkinkan sebagian responden pada kelompok brainstorming lupa tentang materi tanda bahaya kehamilan, persalinan, dan nifas yang sudah didapat.

Metode Pendidikan Kesehatan brainstorming dan buzz group meningkatkan pengetahuan suami ibu hamil tentang tanda bahaya kehamilan, persalinan, dan nifas di wilayah Puskesmas Sukamakmur Kabupaten Bogor. Metode buzz group dapat meningkatkan pengetahuan responden tentang tanda bahaya yang lebih baik dibandingkan metode brainstorming.

\section{KESIMPULAN}

Metode Pendidikan Kesehatan brainstorming dan buzz group dapat meningkatkan pengetahuan suami ibu hamil tentang tanda bahaya kehamilan, persalinan, dan nifas di wilayah Puskesmas Sukamakmur Kabupaten Bogor. Metode buzz group adalah lebih baik dalam meningkatkan pengetahuan suami ibu hamil tentang tanda bahaya dibandingkan dengan metode brainstorming.

Hasil penelitian ini dapat menjadi informasi bagi Dinas Kesehatan Kabupaten Bogor untuk mengembangkan kebijakan tentang metode Pendidikan Kesehatan pada masyarakat, khususnya suami yang istrinya sedang hamil. Bidan desa sebagai tenaga kesehatan yang memiliki hubungan dekat dengan masyarakat dapat menerapkan metode Pendidikan Kesehatan brainstorming dan buzz group pada suami ibu hamil di wilayahnya.

\section{UCAPAN TERIMA KASIH}

Ucapan terima kasih kepada Pemerintah Indonesia khususnya Kementerian Kesehatan dan Poltekkes Kemenkes Jakarta III yang telah memberi kesempatan pada penulis untuk tugas belajar, kepada keluarga dan orang tua yang senantiasa memberi dukungan penuh serta tim pembimbing yang telah sabar dan penuh keikhlasan membimbing penulis selama penyusunan karya ilmiah. Terima kasih juga kepada pemerintah Kabupaten Bogor yang telah memberi izin untuk melakukan penelitian, Puskesmas Sukamakmur khususnya Bidan desa dan kader kesehatan di desa Cibadak dan Desa Sirnajaya sebagai lokasi penelitian serta suami ibu hamil di lokasi penelitian yang berpartisipasi dalam kegiatan penelitian ini 


\section{DAFTAR PUSTAKA}

Arshed AW, Ch KM, Iqbal M, Hussain A., 2012., Effectiveness of extension education methods used by Rafhan Maize Products for information dissemination to maize growers of Central Punjab, Pakistan. Pakistan J Food Sei. pp.22:36-9.

Aimanah IU, Astuti WD, Kalimah ST., 2011. Laporan akhir penelitian Risbinkes: Peran suami dan keluarga ibu hamil dalam Perencanaan Persalinan dan Pencegahan Komplikasi di Kabupaten Sampang dan Kabupaten Situbondo Jawa Timur. Jakarta: Badan Penelitian dan Pengembangan Kesehatan Kemenkes RI.

Balitbangkes. Laporan hasil riset kesehatan dasar (RISKESDAS) Indonesia tahun 2007. Jakarta: Badan Penelitian dan Pengembangan Kesehatan Kemenkes RI

BPS, BKKBN, Depkes, Macro O. 2008. Survei Demografi dan Kesehatan Indonesia. Jakarta: Kemenkes RI.

Dinkes. Profil kesehatan Kabupaten Bogor 2010. Bogor: Dinas Kesehatan Kabupaten Bogor.

Harymawan., 2007. Dukungan suami dan keluarga. Jakarta: www.infomedia.com; [cited 201320 Juni].

Hapsari S., 2007. Efektivitas metode curah pendapat dalam meningkatkan pengetahuan dan sikap mengenai ASI eksklusif pada ibu hamil. Semarang. http://eprint; [cited $2013 \quad 19$ September].

Kakaire O, Kaye DK, Osinde MO. 2011. Male involvement in birth preparedness and complication readiness for emergency obstetric referral in rural Uganda. Reprd Health BioMed Central J., pp 8:1-7.

Kemenkes, BKKBN, BPS. 2012. Survey Demografi Kesehatan Indonesia In: RI K, editor. Jakarta: Kemenkes RI.
Kemenkes, UNFPA., 2012. Disparitas akses dan kualitas: Kajian determinan kematian maternal di lima region Indonesia. Jakarta: Kemenkes RI.

2012. Laporan praktik kebidanan komunitas. Jakarta: Jurusan Kebidanan Poltekkes Jakarta II

Mullany BC, Becker S, Hindin MJ. 2007. The impact of including husbands in antenatal health education services on maternal health practices in urban Nepal: results from a randomized controlled trial. Health Educ research Oxford J., pp: 22:166-76.

Norhajati, Dewi VK, Inayah HK., 2010. Pendidikan kesehatan dengan metode ceramah dan roleplay pada ibu hamil tentang tanda bahaya kehamilan. Jurnal Skala Kesehatan Politeknik Kesehatan Banjarmasin.

Notoatmodjo S., 2012 Metodologi penelitian kesehatan. Jakarta: Rineka Cipta.

Nurlianawati L., 2012. pengaruh Diskusi Kelompok Tentang Perawatan Kehamilan Terhadap Pengetahuan dan Sikap Keluarga dalam Perawatan Kehamilan di bawah Umur 20 Tahuan di Wilayah Kerja Puskesmas Cihampelas Kabupaten Bandung Barat. Bandung: UNPAD

Rachmawati T D., 2013 Laporan akhir penelitian riset evaluatif implementasi jaminan persalinan. Surabaya: Pusat Humaniora Badan Penelitian dan Pengembangan Kesehatan Kemenekes RI

Roetiyah. Strategi belajar mengajar., 2001. Jakarta: Bina Aksara

Russell, 2013., Associates. Buzz Group : What are Buzz Group? : http://www.ejournal.com/image/buzzsyndic; [cited 2013 September 19].

Satari MH, Wirakusumah FF. 2011. Konsistensi penelitian dalam bidang kesehatan. Bandung: Refika Aditama

Scout, Association. 2013. Buzz Group. http://members.scouts.org.uk; [cited 2013 September 19]. 
The Southeast Asian Journal of Midwifery Vol. 1, No.1, Oktober 2015, Hal: 1-9

Sholihah I. Faktor-faktor yang berhubungan dengan pengetahuan suami tentang tanda bahaya pada masa kehamilan, persalinan, nifas dan neonatus di Kabupaten Garut Jawa Barat. Media Litbang Kesehatan. Pp: 19:89-100.

Sucipto B., 2006. Penggunaan metode Pembelajaran (suatu metaanalisis kajian tesis). Jakarta: Program Pasca Sarjana UN Jakarta

Tormey R. 2012. ABC of Buzz Groups. London: http://craft.epfl.ch/file/content/sites/craft3; [cited 2013 September 19].

Winarsi. 2006. Pendidikan kesehatan mengatasi keluhan dalam kehamilan pada ibu hamil di asrama Grup Kopasus Kartasura. Kartasura: www.eprint.ums.ac.id/ournal/index.php; [cited 201320 Juni].

Wijono D., 2008. Manajemen kesehatan ibu dan anak: prinsip dan strategi pendekatan komunitas. Surabaya: Duta Prima Erlangga 